University of Nebraska - Lincoln

DigitalCommons@University of Nebraska - Lincoln

\title{
Continuous production of extracellular antioxidants in suspension cells attenuates the oxidative burst detected in plant microbe interactions
}

\author{
C. Jacyn Baker \\ USDA, jacyn.baker@ars.usda.gov \\ Nichole R. O'Neil \\ USDA \\ Kenneth Deahl \\ USDA \\ John Lydon \\ USDA
}

Follow this and additional works at: https://digitalcommons.unl.edu/usdaarsfacpub

Part of the Agricultural Science Commons

Baker, C. Jacyn; O'Neil, Nichole R.; Deahl, Kenneth; and Lydon, John, "Continuous production of extracellular antioxidants in suspension cells attenuates the oxidative burst detected in plant microbe interactions" (2002). Publications from USDA-ARS / UNL Faculty. 339.

https://digitalcommons.unl.edu/usdaarsfacpub/339

This Article is brought to you for free and open access by the U.S. Department of Agriculture: Agricultural Research Service, Lincoln, Nebraska at DigitalCommons@University of Nebraska - Lincoln. It has been accepted for inclusion in Publications from USDA-ARS / UNL Faculty by an authorized administrator of DigitalCommons@University of Nebraska - Lincoln. 


\title{
Continuous production of extracellular antioxidants in suspension cells attenuates the oxidative burst detected in plant microbe interactions ${ }^{\S}$
}

\author{
C. Jacyn Baker ${ }^{\mathrm{a}, *}$, Nichole R. O’Neill ${ }^{\text {a }}$, Kenneth Deahl ${ }^{\mathrm{b}}$, John Lydon ${ }^{\mathrm{c}}$ \\ ${ }^{a}$ Molecular Plant Pathology Laboratory, Plant Sciences Institute, USDA, Beltsville, MD 20705, USA \\ ${ }^{\mathrm{b}}$ Vegetable Laboratory, Plant Sciences Institute, USDA, Beltsville, MD 20705, USA \\ c Sustainable Agricultural Systems Laboratory, Plant Sciences Institute, USDA, Beltsville, MD 20705, USA
}

Received 7 December 2001; accepted 7 March 2002

\begin{abstract}
Suspension cells of Solanacearum tuberosum and Nicotiana tabacum placed in fresh buffer rapidly produce and maintain significant pools of extracellular antioxidants. The extracellular antioxidant was detected by first adding a known amount of exogenous $\mathrm{H}_{2} \mathrm{O}_{2}$ to samples and then immediately measuring the remaining $\mathrm{H}_{2} \mathrm{O}_{2}$. The difference between the amount added and amount remaining was used to determine the antioxidant capacity of the sample. This extracellular antioxidant pool attenuates levels of hydrogen peroxide produced during plant-bacterial interactions. When tobacco cells were inoculated with an isolate Pseudomonas syringae pv. syringae that causes a hypersensitive response much of the antioxidant capacity had been expended neutralizing the oxidative burst characteristic of such plant-microbe interactions. After a brief delay, the levels of extracellular phenolics increased commensurate to antioxidative capacity in freshly transferred cells within 2-4 h. The strong UV absorbance of these extracellular phenolics within 250 and $350 \mathrm{~nm}$ was used to follow oxidation upon reaction with $\mathrm{H}_{2} \mathrm{O}_{2}$. This extracellular antioxidant pool is an important consideration in cell suspension studies of the plant-microbe oxidative burst. This study demonstrates that the true magnitude and timing of the oxidative burst in cell suspensions is masked by extracellular antioxidants. (C) 2002 Éditions scientifiques et médicales Elsevier SAS. All rights reserved.
\end{abstract}

Keywords: Antioxidants; Cell wall; Hydrogen peroxide; Phenolics; Potato; Suspension-cells; Tobacco

\section{Introduction}

Extracellular phenolics play important functions in plants ranging from cell wall reinforcement to antibiotics and antioxidants. Lignin and polysaccharide bound phenolics cause physical and chemical changes in the plant cell wall that protect it from physical challenges and attack by various pathogens $[4,6,7,9,12]$. Antibiotic phenols can be both constitutive and induced at the site of infection [3,8,11]. A key cell wall metabolite is ascorbic acid, which in association with other components, is an antioxidant that

\footnotetext{
Abbreviations: cfu, colony forming units; HR, hypersensitive response

* Corresponding author.

E-mail address: bakerc@ba.ars.usda.gov (C. Jacyn Baker).

$\S$ Mention of a trade name, proprietary product, or vendor does not constitute a guarantee of the product by the United States Department of Agriculture and does not imply its approval to the exclusion of other vendors that may also be suitable.
}

can protect plants and cells from oxidative damage derived from many sources including pollution, pathogens, photosynthesis and the aerobic environment $[5,14,16]$. A unique and critical role of the ascorbic acid and other phenolic antioxidants in the apoplast along with peroxidases may help to regulate the redox potential of the apoplast $[15,16]$. This phenomenon has serious implications regarding the triggering of other mechanisms and how the cell will react to various stimuli.

In this study, we report the antioxidative buffering capacity of this extracellular phenolic pool and its affect on our ability to detect the plant-microbial oxidative burst. It had been noticed in the previous study that suspension cells of tobacco that were treated with non-hypersensitive response (HR)-causing bacteria accumulated an antioxidant capacity that could rapidly scavenge exogenously added hydrogen peroxide. At that time, the source of this activity and its implications were not understood. In the current study, we demonstrate the potential antioxidative buffering 


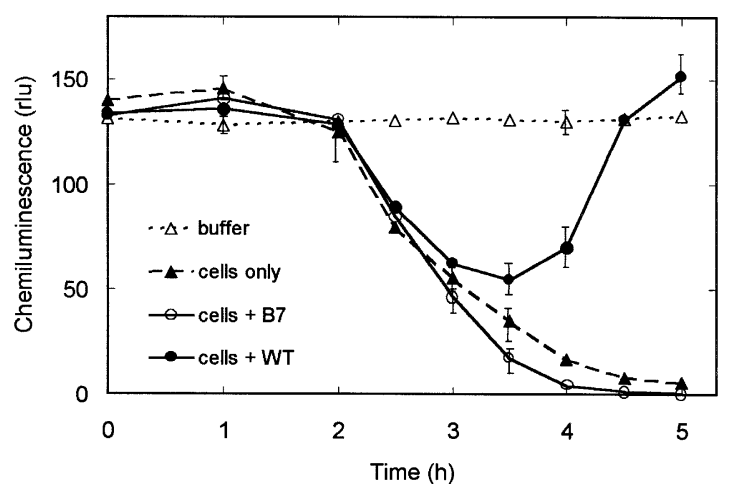

Fig. 1. Tobacco cell suspensions were inoculated with $P$. syringae pv. syringae, $2.5 \times 10^{7} \mathrm{cfu} \mathrm{m}^{-1}$, and monitored for antioxidative capacity. Exogenous $\mathrm{H}_{2} \mathrm{O}_{2}, 50 \mu \mathrm{M}$, was added to samples of treated cells and the remaining $\mathrm{H}_{2} \mathrm{O}_{2}$ was immediately determined by luminol-dependentchemiluminescence, as described in the Methods. Treatments included buffer control, cells with no treatment, and cells inoculated with either HR-causing (WT) or non-HR-causing (B7) isolates of P. syringae pv. syringae. Chemiluminescence is shown in relative light units (rlu).

capacity which can buildup rapidly in cell suspensions and cause an underestimation of the actual oxidative stress.

\section{Results}

Monitoring antioxidative capacity of cell suspensions could be achieved by the addition of exogenous $\mathrm{H}_{2} \mathrm{O}_{2}$ followed by an immediate measurement of the remaining $\mathrm{H}_{2} \mathrm{O}_{2}$ (Fig. 1). The buffer control to which $20 \mu \mathrm{M} \mathrm{H}_{2} \mathrm{O}_{2}$ are added remained relatively constant throughout the monitoring period. Cells with no treatment or treated with the non-HR-causing isolate, $P$. syringae pv. syringae $\mathrm{B} 7$, were able to consume increased amounts of exogenous $\mathrm{H}_{2} \mathrm{O}_{2}$ as time increased. While the initial consumption of $\mathrm{H}_{2} \mathrm{O}_{2}$ in treatments with the HR-causing isolate, P. syringae pv. syringae (WT), was similar to $\mathrm{B} 7$, after $3 \mathrm{~h}$ the consumption of exogenous $\mathrm{H}_{2} \mathrm{O}_{2}$ decreased relative to the other treatments. This would be consistent with previous work that demonstrates $\mathrm{H}_{2} \mathrm{O}_{2}$ is produced during HR reactions [1]. The $\mathrm{H}_{2} \mathrm{O}_{2}$ produced by these treatments was scavenged by the antioxidants and therefore less exogenous $\mathrm{H}_{2} \mathrm{O}_{2}$ could be consumed. This experiment indicates a method by which an oxidative burst may be detected even though $\mathrm{H}_{2} \mathrm{O}_{2}$ does not accumulate.

The antioxidant capacity is defined as the amount of $\mathrm{H}_{2} \mathrm{O}_{2}$ consumed by a quantity of cells as described in the Methods. The antioxidant capacity of a suspension of tobacco and potato cells increased over a $5 \mathrm{~h}$ incubation period (Fig. 2). Phenolics from the same cells were found to increase over the same time period (Fig. 3). The antioxidant capacity as well as the amount of phenolics reached higher levels in tobacco than in potato cell suspensions.

The antioxidant capacity was associated with the extracellular fluid (Fig. 4). The supernatant from suspensions that had been incubated for $5 \mathrm{~h}$ had nearly $95 \%$ of the activity of

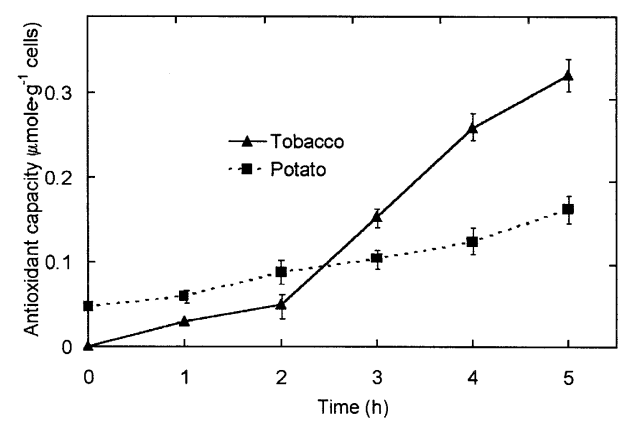

Fig. 2. Cell suspensions of potato and tobacco were monitored for antioxidant capacity over a $5 \mathrm{~h}$ period. Details of the procedures are described in the Methods. Exogenous $\mathrm{H}_{2} \mathrm{O}_{2}, 20 \mu \mathrm{M}$ for potato and $50 \mu \mathrm{M}$ for tobacco, was added to samples of non-treated cells and the remaining $\mathrm{H}_{2} \mathrm{O}_{2}$ was immediately determined by luminol-dependentchemiluminescence. The amount consumed per gram cells is defined as the antioxidant capacity.

the cell suspension, while the cell residue retained less than $5 \%$ antioxidant capacity. The extracellular antioxidant was heat stable, retaining more than $80 \%$ activity after autoclaving for $10 \mathrm{~min}$.

The increase in antioxidant activity in the suspension cells paralleled an increase in absorbance in the 250-350 nm range characteristic of phenolics (Fig. 5A, B). Samples of fresh cell suspensions were scanned hourly in a spectrophotometer. Peaks at 278 and $318 \mathrm{~nm}$ were predominant in potato samples and peaks at 288 and $314 \mathrm{~nm}$ were predominant in tobacco samples. Incremental addition of

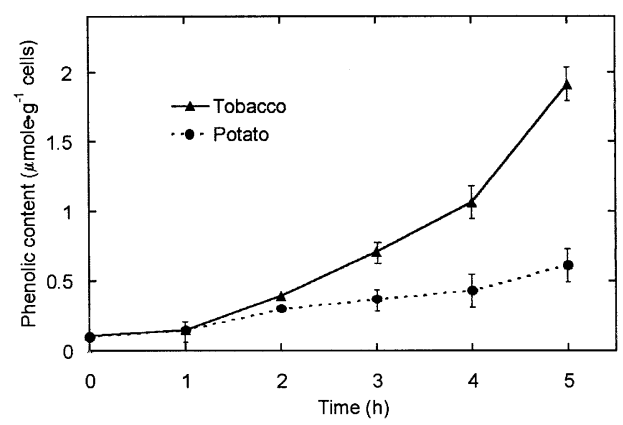

Fig. 3. Cell suspensions of potato and tobacco were monitored for phenolic substances over a $5 \mathrm{~h}$ period. Details of the procedure are described in the Methods.

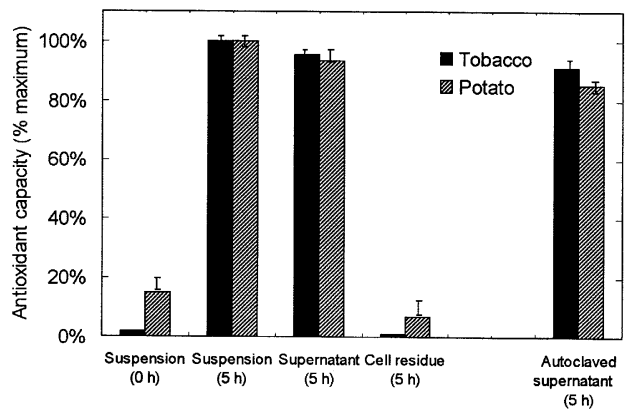

Fig. 4. Antioxidant capacity of various cell suspension treatments were determined using procedures described in the Methods. 


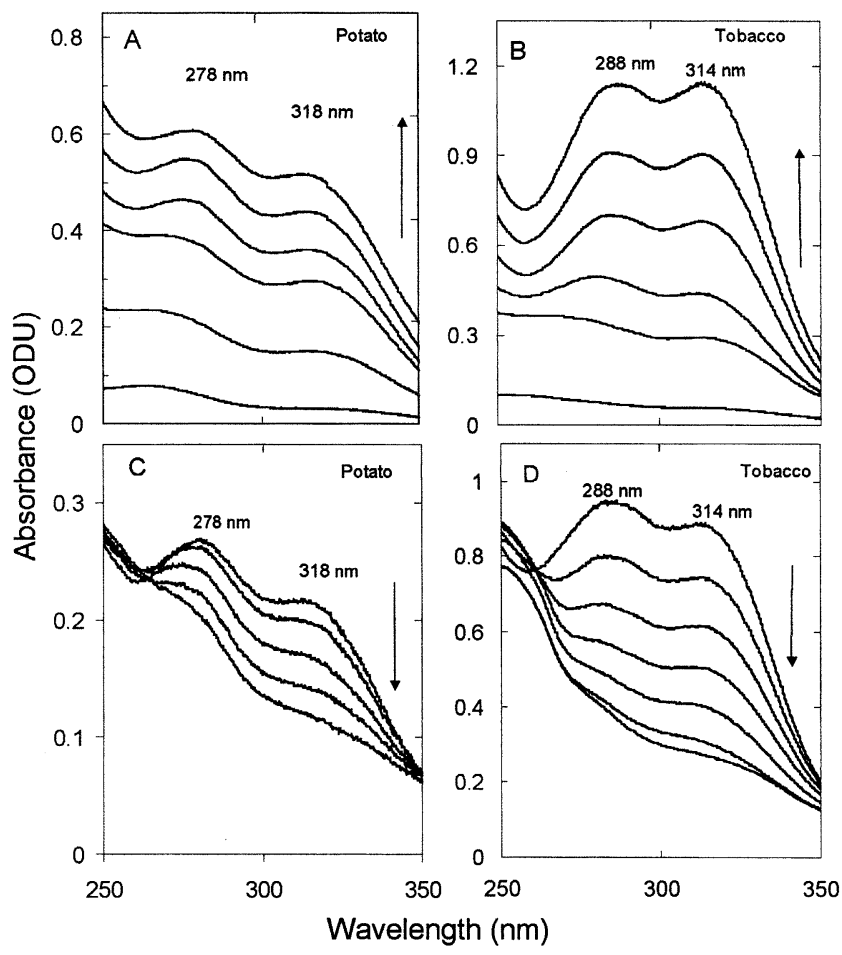

Fig. 5. Absorbance scans of cell suspensions were monitored from 250 to $350 \mathrm{~nm}$. The increase in predominate peaks of potato (A) and tobacco (B) were observed over a $5 \mathrm{~h}$ period. The $5 \mathrm{~h}$ supernatant was scanned after being treated with sequential additions of $\mathrm{H}_{2} \mathrm{O}_{2}: 5$ or $10 \mu \mathrm{M}$ additions for potato (C) or tobacco (D) supernatant, respectively.

$\mathrm{H}_{2} \mathrm{O}_{2}$ to the $5 \mathrm{~h}$ supernatant samples of both cells caused an incremental decrease in absorbance of these peaks (Fig. 5C, D).

Peroxidase appears to be required for this antioxidant phenomenon. Addition of $\mathrm{H}_{2} \mathrm{O}_{2}$, without peroxidase, to the autoclaved $5 \mathrm{~h}$ supernatants did not cause a decrease in absorbance. To determine if peroxidase activity increases significantly during this period we followed peroxidase activity using a standard guaiacol assay as described in the Methods. Peroxidase activity remained about $7 \times 10^{-8}$ and $35 \times 10^{-8}$ katals g $^{-1}$ cells for potato and tobacco, respectively, over the $5 \mathrm{~h}$ period.

\section{Discussion}

The results suggest that healthy suspension cells of tobacco and potato have significant extracellular pools of phenolic compounds that can attenuate the oxidative burst resulting from stresses such as microbial attack. The extracellular phenolic content of suspension cells of either tobacco or potato increased concurrently with scavenging or antioxidant capacity (Figs. 2, 3). The scavenging activity of the extracellular phenolic extracts could be followed spectrophotometrically by decreased absorbance in the 270-320 nm range after addition of hydrogen peroxide (Fig. $5)$.
When cells of tobacco were inoculated with a pathogen, Pseudomonas syringae pv. syringae, it was clear that part of the oxidative burst was buffered by the extracellular phenolics (Fig. 1). Untreated cells or cells treated with the non-HR-causing isolate B7 scavenged more of the exogenously added $\mathrm{H}_{2} \mathrm{O}_{2}$ compared to the treatment with WT. This we believe was due to the oxidative burst produced in the WT treatment, which consumed or oxidized the extracellular antioxidants, thus reducing the antioxidant capacity of these samples. It appears that free $\mathrm{H}_{2} \mathrm{O}_{2}$ will not accumulate in the extracellular supernatant of cell suspensions until the antioxidant buffer pool has been consumed.

The antioxidant capacity of the leaf apoplast has been studied extensively especially in regard to ascorbic acid and ozone tolerance $[15,17]$. Ozone will produce a chronic stress of reactive oxygen species in the apoplast. Ascorbic acid and extracellular phenolics along with peroxidases attenuate the level of reactive oxygen species encountered by the leaf cells. It appears likely that phenolic compounds react directly with peroxidase and $\mathrm{H}_{2} \mathrm{O}_{2}$ while the ascorbic acid serves to regenerate the oxidized phenolic compound. A similar scenario is likely to be occurring in the suspension cell model. It is apparent that a family of phenolics are being produced and the exact composition varies depending on the cell type and age (unpublished data).

This study demonstrates that the oxidative burst caused by HR-causing bacteria in suspension cells is initiated prior to the detection of free $\mathrm{H}_{2} \mathrm{O}_{2}$. Under certain conditions, an oxidative burst may not exceed the antioxidative capacity of the cell suspension. It would be undetectable if free reactive oxygen species were used as the measure. We are currently developing a technique to measure the total oxidative burst in cell suspensions. It will need to account for the oxidative component that is reduced by the extracellular antioxidants as well as the free $\mathrm{H}_{2} \mathrm{O}_{2}$ detected in the supernatant. This information and technique would be applicable to areas in which the oxidative burst is being studied.

\section{Methods}

\subsection{Plant material and bacteria}

Suspension cells of tobacco (Nicotiana tabacum L. cv. Hicks) and potato (Solanum tuberosum cv. Kennebec) were maintained and prepared as previously described [2] except that tobacco callus and suspension cells were maintained on MS media (supplemented with $0.2 \mathrm{mg} \mathrm{l}^{-1} \quad \mathrm{KH}_{2} \mathrm{PO}_{4}$, $0.2 \mathrm{mg} \mathrm{l}^{-1} 2,4-\mathrm{D}$ and $0.1 \mathrm{mg} \mathrm{l}^{-1}$ kinetin). Four-day-old cultures, which were in $\log$ phase, were transferred, $8 \times 80 \mathrm{ml}$ of fresh media in $250 \mathrm{ml}$ flasks. Cells from 4-day-old cultures in log phase growth were washed and suspended in assay buffer (175 mM mannitol, $0.5 \mathrm{mM} \mathrm{CaCl}_{2}, 0.5 \mathrm{mM}$ $\mathrm{K}_{2} \mathrm{SO}_{4}$, and $0.5 \mathrm{mM}$ MES, pH 6) for a final cell concentration of $0.1 \mathrm{~g} \mathrm{ml}^{-1}$. The assay buffer is prepared in bulk and autoclaved to allow storage. It was found that the autoclaved assay buffer should be allowed to equilibrate with air for 
$1 \mathrm{~h}$ prior to use to minimize perturbation of the cells. Cell suspensions, $25 \mathrm{ml}$, contained in $50 \mathrm{ml}$ beakers were equilibrated on a rotary shaker at $180 \mathrm{rpm}$ and $25{ }^{\circ} \mathrm{C}$ for $0.5 \mathrm{~h}$. Bacterial cultures of $P$. syringae pv. syringae 61 were maintained and prepared as previously described [1]. The wild-type (WT) isolate caused an HR reaction on tobacco while the Tn5 insertion mutant (B7) did not. The cultures were grown on Kings B agar plates and suspended in deionized water and added to cell suspension for a final concentration of $2.5 \times 10^{7} \mathrm{cfu} \mathrm{ml}^{-1}$.

\subsection{ROS measurement}

The luminol-dependent chemiluminescent assay was used to measure $\mathrm{H}_{2} \mathrm{O}_{2}$ as an estimate of ROS accumulation [10]. Samples, $0.4 \mathrm{ml}$, of treated suspension cells were dispensed into tubes, placed into the measuring chamber of an EG\&G Berthold Autolumat 953 luminometer (Bad Wildbad, Germany), and automatically mixed with horseradish peroxidase, final concentration $0.72 \mathrm{U} \mathrm{ml}^{-1}$, followed by luminol, final concentration $85 \mu \mathrm{M}$, for immediate measurement of luminescence. Standard curves were prepared with dilutions of $\mathrm{H}_{2} \mathrm{O}_{2}$ in assay buffer (pH6). Antioxidant capacity was calculated by determining the $\mu \mathrm{mol}$ of $\mathrm{H}_{2} \mathrm{O}_{2}$ consumed per gram of cells. Exogenous $\mathrm{H}_{2} \mathrm{O}_{2}, 20 \mu \mathrm{M}$ for potato cells or $50 \mu \mathrm{M}$ for tobacco cells, was added to samples by the luminometer, and the remaining $\mathrm{H}_{2} \mathrm{O}_{2}$ immediately measured. The exogenous $\mathrm{H}_{2} \mathrm{O}_{2}$ was injected after the peroxidase and prior to the luminol. The difference between the samples and buffer with no cells was considered the amount of $\mathrm{H}_{2} \mathrm{O}_{2}$ consumed by the antioxidant.

\subsection{Phenol assay}

The phenolic concentration was determined using the Folin-Ciocalteu method of Singleton and Rossi [13] as described by Booker and Miller [3]. We used $200 \mu \mathrm{l}$ of sample plus $70 \mu \mathrm{l}$ of the $2 \mathrm{~N}$ Folin-Ciocalteu followed $3 \mathrm{~min}$ later with $1 \mathrm{M} \mathrm{Na}_{2} \mathrm{CO}_{3}$. The samples were read $1 \mathrm{~h}$ later at $724 \mathrm{~nm}$ using 4-coumaric acid as a standard.

\subsection{Spectrophotometric scans}

Absorbance scans were carried out on the supernatant of the cell suspension treatments. Samples were filtered through cheesecloth into $1 \mathrm{ml}$ quartz cuvettes. Scans were performed hourly on a Beckman Model DU-650 spectrophotometer between 210 and $400 \mathrm{~nm}$. The $5 \mathrm{~h}$ supernatant was scanned after being treated with sequential additions of $\mathrm{H}_{2} \mathrm{O}_{2}$ : 5 or $10 \mu \mathrm{M}$ additions for potato or tobacco supernatant, respectively.

\subsection{Peroxidase assay}

Peroxidase activity was assayed using a modified guaiacol assay. Samples of cell suspension treatments were assayed for enzyme activity in a reaction mixture containing $1 \mathrm{mM}$ guaiacol, $50 \mathrm{mM}$ MES buffer (pH6) and $1 \mathrm{mM} \mathrm{H}_{2} \mathrm{O}_{2}$. The change in absorbance was measured at $475 \mathrm{~nm}$ in a spectrophotometer at $27^{\circ} \mathrm{C}$.

\section{References}

[1] C.J. Baker, G.L. Harmon, J.A. Glazener, E.W. Orlandi, A noninvasive technique for monitoring peroxidative and $\mathrm{H}_{2} \mathrm{O}_{2}$-scavenging activities during interactions between bacterial plant pathogens and suspension cells, Plant Physiol. 108 (1995) 353-359.

[2] C.J. Baker, N.M. Mock, K. Deahl, J. Domek, Monitoring the rate of oxygen consumption in plant cell suspensions, Plant Cell, Tissue Organ Cult. 51 (1997) 111-117.

[3] F.L. Booker, J.E. Miller, Phenylpropanoid metabolism and phenolic composition of soybean [Glycine max (L.) Merr.] leaves following exposure to ozone, J. Exp. Bot. 49 (1998) 1191-1202.

[4] C.T. Brett, G. Wende, A.C. Smith, K.W. Waldron, Biosynthesis of cell-wall ferulate and diferulates, J. Sci. Food Agric. 79 (1999) $421-424$.

[5] F. Castillo, H. Greppin, Extracellular ascorbic acid and enzyme activities related to ascorbic acid metabolism in Sedum album L. leaves after ozone exposure, Environ. Exp. Bot. 28 (1988) 231-238.

[6] R. Franke, S.C. Fry, H. Kauss, Low-molecular-weight precursors for defense-related cell wall hydroxycinnamoyl esters in elicited parsley suspension cultures, Plant Cell Rep. 17 (1998) 379-383.

[7] S.C. Fry, Cross-linking of matrix polymers in the growing cell walls of angiosperms, Annu. Rev. Plant Physiol. 37 (1986) 165-186.

[8] H. Kauss, R. Franke, K. Krause, U. Conrath, W. Jebllick, B. Grimmig, U. Matern, Conditioning of Parsley (Petroselinum crispum L.) suspension cells increases elicitor-induced incorporation of cell wall phenolics, Plant Physiol. 102 (1993) 459-466.

[9] R.L. Nicholson, R. Hammerschmidt, Phenolic compounds and their role in disease resistance, Annu. Rev. Phytopathol. 30 (1992) 369-389.

[10] E.W. Orlandi, S.W. Hutcheson, C.J. Baker, Early physiological responses associated with race-specific recognition in soybean leaf tissue and cell suspensions treated with $P$. syringae pv Syringae, Physiol. Molec. Plant Pathol. 40 (1992) 173-180.

[11] A. Schmidt, D. Scheel, D. Strack, Elicitor-stimulated biosynthesis of hydroxycinnamoyltyramines in cell suspension cultures of Solanum tuberosum, Planta 205 (1998) 51-55.

[12] P. Schopfer, Hydrogen peroxide-mediated cell-wall stiffening in vitro in maize coleoptiles, Planta 199 (1996) 43-49.

[13] V.L. Singleton, J.A. Rossi, Colorimetry of total phenolics with phosphomolybdic-phosphotungstic acid reagents, Am. J. Enol. Viticult. 16 (1965) 144-158.

[14] N. Smirnoff, The function and metabolism of ascorbic acid in plants, Ann. Bot. 78 (1996) 661-669.

[15] U. Takahama, Redox state of ascorbic acid in the apoplast of stems of Kalanchoe daigremontiana, Physiol. Plant 89 (1993) 791-798.

[16] U. Takahama, Ascorbic acid-dependent regulation of redox levels of chlorogenic acid and its isomers in the apoplast of leaves of Nicotiana tabacum L, Plant Cell Physiol. 39 (1998) 681-689.

[17] E. Turcsanyi, T. Lyons, M. Plochl, J. Barnes, Does ascorbate in the mesophyll cell walls form the first line of defence against ozone? Testing the concept using broad bean (Vicia faba L.), J. Exp. Bot. 51 (2000) 901-910. 